\title{
Adenocarcinoma mimicking eruptive xanthomas clinically
}

\author{
Savita Chaudhary, ${ }^{1}$ Cherry Bansal ${ }^{2}$
}

${ }^{1}$ Department of Dermatology, Era's Lucknow Medical College, Lucknow, Uttar Pradesh, India ${ }^{2}$ Department of Pathology, King George's Medical University (erstwhile CSMMU), Lucknow, Uttar Pradesh, India

\section{Correspondence to}

Dr Cherry Bansal,

drcherrybansal@gmail.com
To cite: Chaudhary $S$ Bansal C. BMJ Case Rep Published online: [please include Day Month Year] doi:10.1136/bcr-2013009715

\section{DESCRIPTION}

A 40-year-old man presented with a 20-day history of sudden eruption of rapidly growing, multiple, elevated lesions on his thigh. The lesions were not associated with itching, pain, bleeding or pus discharge.

On dermatological examination, multiple clustered, papulonodular, 1-4 cm lesions were identified over anteromedial right thigh (figures 1 and 2). There was no lymphadenopathy or lesions in cornea, eyelids, mucous membranes, palms and Achilles tendon.

After a history was taken and he was examined, a provisional diagnosis of eruptive xanthomas was made. Blood glucose, lipid profile, liver function test were normal and his HIV test was negative. Skin biopsy revealed a tumour arranged in acinar and nested pattern. Cells were pleomorphic with vesicular chromatin and prominent nucleoli (figure 3). Differentials of malignant adnexal tumour and cutaneous metastasis from adenocarcinoma were considered. CT scan was performed for tumour origin and other sites involved by metastases. CT scan showed multiple metastatic deposits in vertebral column and pelvis. However, no definite primary visceral origin was demonstrated.

To confirm tumour origin, immunohistochemical (IHC) was performed and podoplanin was negative. The patient is on treatment with completion of first chemotherapy cycle.

Eruptive xanthomas present with a short history of eruption of small, erythematous-to-yellow papules distributed over hands, extensors and buttocks. Early lesions may have an erythematous halo with pruritus and tenderness. ${ }^{1}$

Histomorphological overlap between primary adnexal tumours and cutaneous metastases pose diagnostic challenge but distinction is crucial as their treatment and prognosis differ. Very few studies have

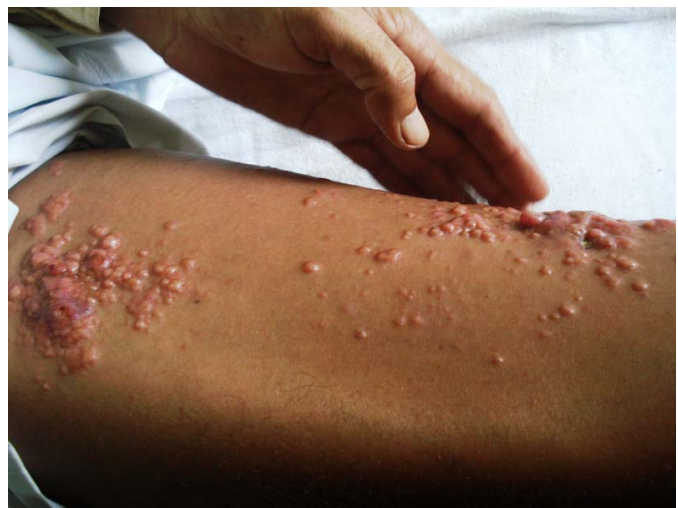

Figure 1 Clustered pattern of papulonodular lesions of size $1 \times 2 \mathrm{~cm}$ to $3 \times 4 \mathrm{~cm}$ present over anteromedial right thigh.

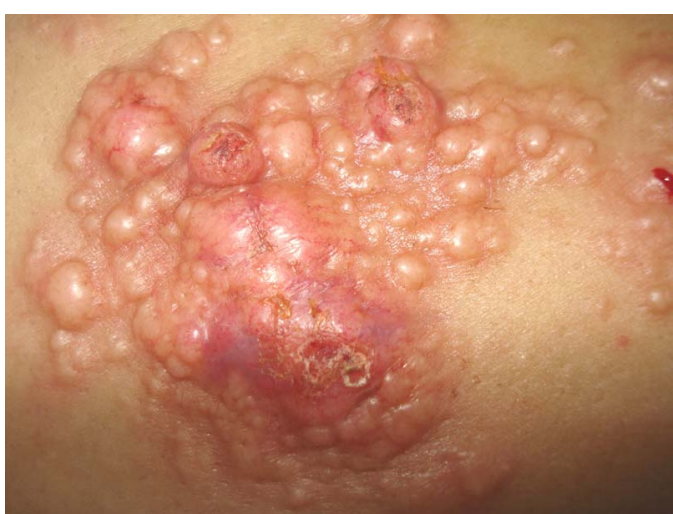

Figure 2 Multiple papulonodular lesions coalesce to form plaque of size $5 \times 6 \mathrm{~cm}$ with ill-defined margins and surface showing erosion and ulceration at places.

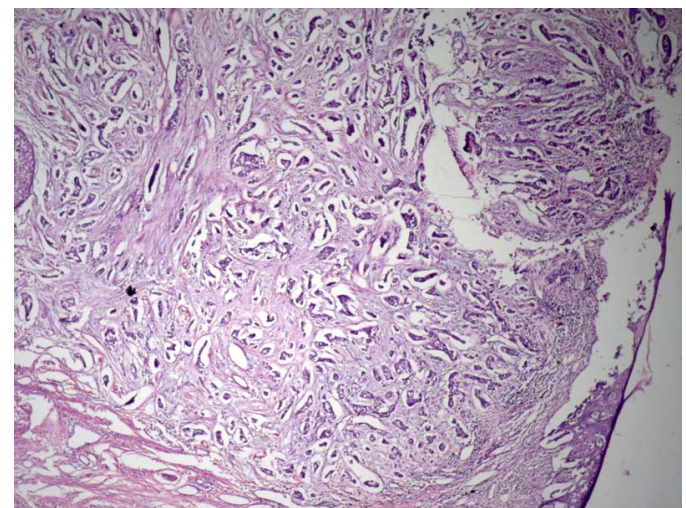

Figure 3 Photomicrograph showing a tumour in dermis and invading the epidermis $(\mathrm{H} \& \mathrm{E} ; \times 100)$.

differentiated them by applying IHC and a definite, cost-effective panel still needs to be worked out. ${ }^{23}$

\section{Learning points}

- Cutaneous tumours can clinically present and mimic eruptive xanthomas dermatologically.

- Histomorphological similarities between primary and metastatic cutaneous tumour often defy precise diagnosis.

- Immunohistochemical tests should be performed to differentiate them so that appropriate treatment can be carried out.

Competing interests None.

Patient consent Obtained.

Provenance and peer review Not commissioned; externally pee reviewed. 


\section{REFERENCES}

1 Massengale WT, Nesbitt LT Jr. Xanthomas. In: Bolognia JL, Jorizzo JL, Rapini PP, eds. Dermatology. New York: Mosby, 2003:1448.

2 Plaza JA, Ortega PF, Stockman DL, et al. Value of p63 and podoplanin (D2-40) immunoreactivity in the distinction between primary cutaneous tumors and adenocarcinomas metastatic to the skin: a clinicopathologic and immunohistochemical study of 79 cases. J Cutan Pathol 2010;37:403-10.

3 Rollins-Raval M, Chivukula M, Tseng GC, et al. An immunohistochemical panel to differentiate metastatic breast carcinoma to skin from primary sweat gland carcinomas with a review of the literature. Arch Pathol Lab Med 2011;135:975-83.

Copyright 2013 BMJ Publishing Group. All rights reserved. For permission to reuse any of this content visit http://group.bmj.com/group/rights-licensing/permissions.

BMJ Case Report Fellows may re-use this article for personal use and teaching without any further permission.

Become a Fellow of BMJ Case Reports today and you can:

- Submit as many cases as you like

- Enjoy fast sympathetic peer review and rapid publication of accepted articles

- Access all the published articles

- Re-use any of the published material for personal use and teaching without further permission

For information on Institutional Fellowships contact consortiasales@bmjgroup.com

Visit casereports.bmj.com for more articles like this and to become a Fellow 